\title{
KAPASITAS SIMPANG BERSINYAL DAN DERAJAT KEJENUHANNYA (STUDI KASUS SIMPANG IV KOTA LHOKSEUMAWE)
}

\author{
Kurnia Anggi Syaputra Nasution \\ Jurusan Teknik Sipil, Fakultas Teknik, Universitas Malikussaleh
}

\begin{abstract}
Abstrak
Persimpangan simpang 4 kota Lhokseumawe merupakan simpang bersinyal yang memiliki lalulintas harian yang tinggi karena jalan merdeka barat dan jalan merdeka timur merupakan salah satu jalan utama dalam ke kota Lhokseumawe, sesuai dengan permasalahan tersebut perumusan masalah untuk penelitian ini adalah bagaimanakah kinerja persimpangan simpang 4 kota Lhokseumawe. Analisis menggunakan metode MKJI 1997 pada masingmasing pendekat timur (jalan Merdeka Timur), pendekat barat (jalan Merdeka Barat), pendekat utara (jalan Pang Lateh), pendekat selatan (jalan Darussalam). Pengambilan data survei dilakukan selama 11 jam per hari. Hasil perhitungan analisis diperoleh nilai kapasitas untuk pendekat timur $2040 \mathrm{smp} / \mathrm{jam}$, pendekat barat $3264 \mathrm{smp} / \mathrm{jam}$, pendekat utara $766 \mathrm{smp} / \mathrm{jam}$ dan pendekat selatan $860 \mathrm{smp} / \mathrm{jam}$ sehingga diperoleh nilai derajat kejenuhan (DS) untuk pendekat timur 0,40 ; pendekat barat 0,26 ; pendekat selatan 0,30 dan pendekat utara 0,30 .
\end{abstract}

Kata kunci : simpang bersinyal, analisis, kinerja, derajat kejenuhan, panjang antrian dan tundaan.

\section{Pendahuluan}

Persimpangan sebagai salah satu tempat pertemuan ruas-ruas jalan dan tempat terjadinya konflik lalulintas, berfungsi sebagai tempat kendaraan melakukan perubahan arah arus lalulintas. Persimpangan dapat bervariasi dari persimpangan sederhana yang terdiri dari pertemuan dua ruas jalan sampai persimpangan kompleks yang terdiri dari pertemuan beberapa ruas jalan. Tingkat kinerja dari simpang sebagai dari jaringan prasarana lalulintas secara keseluruhan menunjukkan tingkat pelayanan yang disajikan bagi pengemudi sebagai pengguna. Tingkat kinerja tersebut digambarkan melalui minimalnya tingkat tundaan yang dialami dan rendah peluang antrian. Persimpangan simpang IV Kota Lhokseumawe memiliki lalulintas harian yang tinggi, terutama pada ruas jalan merdeka barat dan ruas jalan merdeka timur karena jalan merdeka barat dan jalan merdeka timur merupaka salah satu jalan utama dalam ke Kota Lhokseumawe. Adapun tujuan dari penelitian ini adalah: "Kinerja Simpang Bersinyal Simpang IV Kota Lhokseumawe".

Penggunaan lampu lalulintas sebagai salah satu instrument pengaturan dan pengendalian kendaraan serta pejalan kaki di persimpangan,kini semakin popular serta terus berkembang karena berbagai kelebihan yang dimilikinya. Disamping mengurangi tenaga petugas kepolisian (dan instansi terkait lain), pengguanaan lampu lalulintas di persimpangan, sampai batas tertentu, memungkinkan peningkatan kapasitas secara signifikan, mengurangi kecelakaan, menambah tingkat keamanan dan kenyamanan bagi penyeberang jalan dan lain-lain.

Penelitian ini hanya untuk mengetahui tingkat kepadatan lalulintas dipersimpangan yang akan ditinjau antara lain persimpangan bersinyal jalan Kota 
Lhokseumawe yang tingkat pelayanan kurang efisien serta terjadinya tundaan kendaraan dan antrian kendaraan pada jam-jam tertentu. Jenis kendaraan yang diamati antara lain adalah kendaraan ringan yaitu kendaraan bermotor ber as dua dan dengan 4 roda dengan jarak as 2,0-3,0 m (meliputi; mobil penumpang, minibus, pick up) kendaraan berat yaitu kendaraan bermotor dengan lebih dari 4 roda (meliputi; bis, truk 2 as) sepeda motor yaitu kendaraan bermotor dengan 2 atau 3 roda (meliputi; sepeda motor, kendaraan roda 3. Kondisi lingkungan yang menjadi bahan pertimbangan antara lain adalah hambatan samping yang terdapat disekitar akses jalan, yaitu adanya parkir kendaraan tidak sesuai pada tempatnya, pejalan kaki tidak ditrotoar, pedagang kaki lima, penghentian angkot dan kendaraan lainnya.

\section{Tinjauan Kepustakaan}

Menurut Anonim (1997), Simpang-simpang bersinyal yang merupakan bagian dari sistem kendali waktu tetap yang dirangkai atau sinyak actual kendaraan terisolir, biasanya memerlukan metode dan perangkat lunak khusus dalam analisanya. Pada umumnya sinyal lalulintas dipergunakan untuk satu atau lebih dari alasan berikut:

a. Untuk menghindari kemacetan simpang akibat adanya konflik arus lalu lintas, sehingga terjamin bahwa suatu kapasitas tertentu dapat dipertahankan, bahkan selama kondisi lalulintas jam puncak;

b. Untuk memberikan kesempatan untuk kendaraan dan/atau pejalan kaki dari jalan simpang (kecil) untuk memotong jalan utama;

c. Untuk mengurangi jumlah kecelakaan lalulintas akibat tabrakan antara kendaraan-kendaraan dari arah bertentangan.

\subsection{Lalulintas}

Umumnya lalulintas dijalan raya terdiri dari campuran kendaraan cepat, kendar aan lambat, kendaraan berat, kendaraan ringan dan kendaraan tak bermotor. Dalam hubungannya derngan kapasitas jalan pengaruh dari setiap jenis kendaraan tersebut terhadap keseluruhan arus lalulintas, diperhitungan dengan membandingkan terhadap pengaruh mobil penumpang. Hal ini dipakai sebagai satuan dan disebut 'satuan mobil penumpang' (SMP).

\subsubsection{Persimpangan sebidang}

Persimpangan yang dimaksud adalah pertemuan satu bidang antara dua jalur atau lebih pada jalan raya. Pertimbangan yang perlu diperhatikan dalam perencanaan alinyemen untuk simpang sebidang antara dua jalur jalan raya adalah keadaan topografi dan geografi sekitarnya, kemantapan alinyemen simpang yaitu adanya koordinasi alinyemen horizontal dan alinyemen vertical, keamanan bagi pengemudi, penumpang dan pejalan kaki, dan Keterbatasan alokasi dana.

Menurut Hobs (1995), pertemuan jalan yang memiliki semua gerakan membelok, maka jumlah simpang pada jalan tersebut tidak boleh lebih dari empat lengan, demi kesederhanaan dalam perencangan dan pengoperasiannya. Hal ini untuk membatasi titik konflikdan membantu pengemudi untuk mengamati keadaan. Simpang sebidang dengan sinyal merupakan pertemuaan atau perpotongan pada satu bidang antara dua atau lebih jalur jalan raya dengan lalulintas masing-masing, dan pada titik-titik simpang dilengkapi dengan sinyal. 


\subsubsection{Persimpangan Tak Sebidang}

Menurut Munawar (2004), adanya pemasangan lampu lalulintas, maka kecelakaan yang timbul diharapkan dapat berkurang, karena konflik yang timbul antara arus lalulintas dapat dikurangi. Gerakan dan manuver kendaraan dapat dibagi dalam beberapa katagori dasar, yaitu: pemisahan (diverging), penggabungan (merging), menyelip berpindah jalur (weaving) dan penyilangan (crossing). Contoh perbandingan antara jumlah konflik yang terjadi pada simpang dengan lampu lalulintas adalah sebagai berikut:

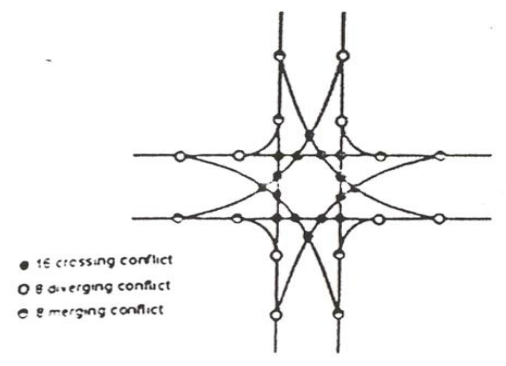

a. dengan rambu lalulintas

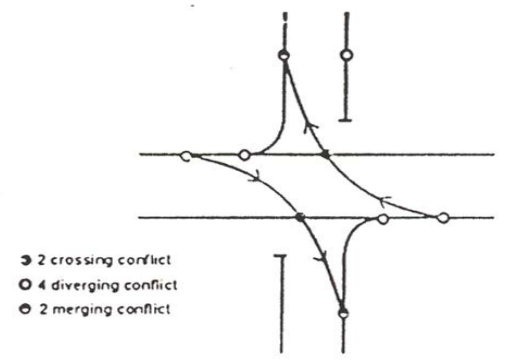

b. dengan lampu lalulintas

Gambar 1 Konflik lalulintas pada simpang empat lengan

Sumber : Manajemen Lalulintas Perkotaan, Ahmad Munawar, 2004

Pola urutan lampu lalulintas yang digunakan di Indonesia mengacu pada pola yang dipakai di Amerika Serikat, yaitu: merah (red), kuning (amber) dan hijau (green). Hal ini untuk memisahkan atau menghindari terjadinya konflik akibat pergerakan lalulintas lainnya. Pemasangan lampu lalulintas pada simpang ini dipisahkan secara koordinat dengan sistem kontrol waktu secara tetap atau dengan bantuan manusia.

\subsubsection{Data Masukan}

a. Kondisi geometri dan lingkungan: Berisi tentang informasi lebar jalan, lebar bahu jalan, lebar median dan arah untuk tiap lengan simpang. Kondisi lingkungan ada tiga tipe yaitu: komersial, pemukiman dan akses terbatas.

b. Kondisi arus lalulintas: Jenis kendaraan dibagi dalam beberapa tipe, seperti diperlihatkan pada Tabel 1 dan memiliki nilai konversi pada tiap pendekat seperti tersaji pada Tabel 2.

Tabel 1 Tipe Kendaraan

\begin{tabular}{|c|l|c|}
\hline No & \multicolumn{1}{|c|}{ Tipe Kendaraan } & Definisi \\
\hline $\mathbf{1}$ & Kendaraan tak bermotor (UM) & Sepeda, becak \\
$\mathbf{2}$ & Sepeda motor (MC) & Sepeda motor \\
$\mathbf{3}$ & Kendaraan ringan (LV) & Colt,pick up, station wagon \\
$\mathbf{4}$ & Kendaraan berat (HV) & Bus, truck \\
\hline
\end{tabular}

Sumber: Manual Kapasitas Jalan Indonesia (MKJI) 1997

Tabel 2 Nilai konversi smp pada simpang untuk jalan perkotaan

\begin{tabular}{|c|c|c|}
\hline Jenis & \multicolumn{2}{|c|}{ Nilai snp untuk tiap pendekatan } \\
\cline { 2 - 3 } Kendaraan & Terlindung $(\mathbf{P})$ & Terlawan $(\mathbf{0})$ \\
\hline LV & 1,0 & 1,0 \\
HV & 1,3 & 1,3 \\
MV & 0,2 & 0,4 \\
\hline
\end{tabular}

Sumber: Manual Kapasitas Jalan Indonesia (MKJI) 1997 


\subsubsection{Fase Sinyal}

Menurut Munawar (2004), fase adalah suatu rangkaian dari kondisi yang diberlakukan untuk suatu arus atau beberapa arus, yang mendapatkan identifikasi lampu lalulintas yang sama. Jumlah fase yang baik adalah fase yang menghasilkan kapasitas besar dan rata-rata tundaan rendah. Bila arus bolak balik kanan dari satu kaki atau arus belok kana dari kiri lawan arah terjadi pada fase yang sama, arus ini dinyatakan sebagai terlawan (opessed). Arus belok kanan yang dipisahkan fasenya dengan arus lurus atau belok kanan tidak diijinkan, maka arus ini dinyatakan sebagai terlindung (protected). Periode merah semua (all red) antar fase harus sama atau lebih besar dari LT setelah waktu all red ditentukan, total waktu hilang (LT) dapat dihitung sebagai penjumlahan periode waktu antar hijau (IG). Panjang waktu kuning pada sinyal lalulintas perkotaan di Indonesia biasanya 3 detik. Penentuan waktu sinyal

1. Pemilihan tipe pendekatan (approach): Pemilihan tipe pendekatan (approach) yaitu termasuk tipe terlindung $\mathrm{P}$ (protected) atau tipe terlawan $\mathrm{O}$ (opessed $v$ ).

2. Lebar efektif pendekat (approach), We = Effektif Width

a) Untuk pendekat tipe $\mathrm{O}$ (Terlawan)

Jika $W_{\text {LTOR }} \geq 2.0$ meter, maka We =WA - WLTOR

Jika WLTOR $\leq 2.0$ meter, maka We $=$ WA X $(1+$ PLTOR $)-$ WTOR.

Di mana WA adalah Lebar pendekat, WLTOR adalah Lebar pendekat dengan belok kiri langsung

b) Untuk pendekat tipe P: Jika Wkeluar < We x (1 - PRT - PLTOR),We sebaiknya diberi nama baru yaitu Wkeluar, di mana PRT adalah Rasio kendaraan belok kanan, PLTOR adalahRasio kendaraan belok kiri langsung

\subsection{Arus Jenuh Dasar (So)}

Arus jenuh dasar merupakan besarnya keberangkatan antrian di dalam pendekat selama kondisi ideal (smp/jam hijau).
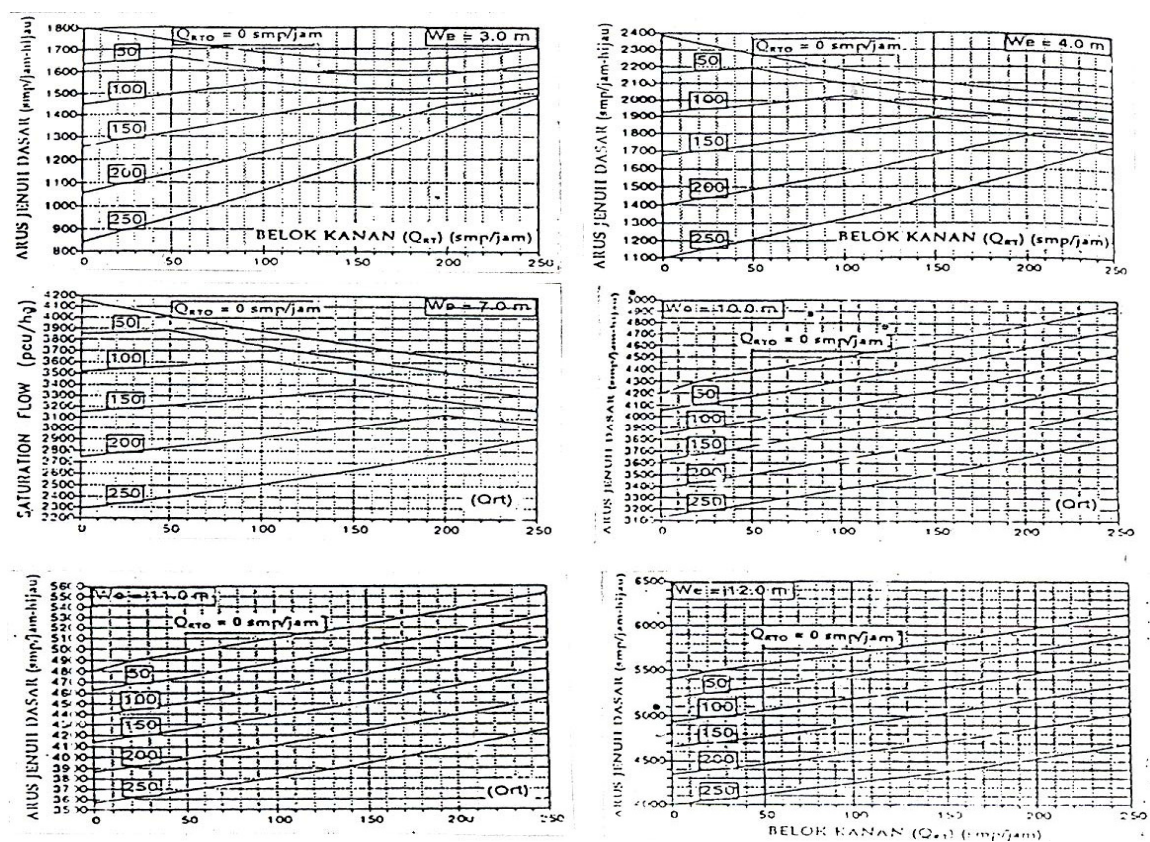

Gambar 2 Grafik arus jenuh dasar untuk pendekat Tipe $\mathbf{O}$ Sumber : Manual Kapasitas Jalan Indonesia (MKJI) 1997 
Untuk tipe pendekat $\mathrm{P}$,

So $=600 \times \mathrm{We}$

Keterangan:

So : Arus jenuh dasar

We : Lebar efektif pendekat

\subsubsection{Faktor Penyesuaian}

1) Penetapan faktor koreksi

Penetapan faktor koreksi untuk nilai arus lalulintas dasar kedua tipe pendekat (protected dan opposed) pada simpang adalah sebagai berikut:

a) Faktor koreksi ukuran kota (Fcs), sesuai Tabel 3:

Tabel 3 faktor koreksi ukuran kota (Fes) untuk simpang

\begin{tabular}{|c|c|}
\hline $\begin{array}{c}\text { Jumlah penduduk } \\
\text { (Dalam juta) }\end{array}$ & $\begin{array}{c}\text { Factor penyesuaian ukuran dalam kota } \\
\text { (Fcs) }\end{array}$ \\
\hline$>3,0$ & 1,05 \\
$1,0-3,0$ & 1,00 \\
$0,5-1,0$ & 0,94 \\
$0,1-1,0$ & 0,83 \\
$<0,1$ & 0,82 \\
\hline
\end{tabular}

Sumber: Manual Kapasitas Jalan Indonesia (MKJI) 1997

b) Faktor koreksi gangguan samping ditentukan sesuai Tabel 4

Tabel 4 faktor koreksi gangguan samping (FSF)

\begin{tabular}{|c|c|c|c|c|c|c|c|c|}
\hline Lingkung & Hambatan & Tipe fase & \multicolumn{5}{|c|}{ Rasio kendaran tak bermotor } \\
\cline { 4 - 8 } an jalan & samping & & $\mathbf{0 , 0 0}$ & $\mathbf{0 , 0 5}$ & $\mathbf{0 , 1 0}$ & $\mathbf{0 , 1 5}$ & $\mathbf{0 , 2 0}$ & $\mathbf{2 0 , 2 5}$ \\
\hline & Tinggi & Terlawan & 0,93 & 0,98 & 0,84 & 0,79 & 0,74 & 0,70 \\
& & Terlindung & 0,93 & 0,91 & 0,88 & 0,87 & 0,85 & 0,81 \\
Komersial & \multirow{2}{*}{ Sedang } & Terlawan & 0,94 & 0,89 & 0,85 & 0,80 & 0,75 & 0,81 \\
$(\mathrm{KOM})$ & & Terlindung & 0,94 & 0,92 & 0,89 & 0,88 & 0,86 & 0,82 \\
& \multirow{2}{*}{ Kecil } & Terlawan & 0,95 & 0.90 & 0,86 & 0,81 & 0,76 & 0,72 \\
& & Terlindung & 0.95 & 0,93 & 0,90 & 0,89 & 0,87 & 0,83 \\
\hline & \multirow{2}{*}{ Tinggi } & Terlawan & 0,96 & 0,91 & 0,86 & 0,81 & 0,78 & 0,72 \\
& & Terlindung & 0,96 & 0,94 & 0,92 & 0,89 & 0,86 & 0,84 \\
Pemukima & \multirow{2}{*}{ Sedang } & Terlawan & 0,97 & 0,92 & 0,87 & 0,82 & 0,79 & 0,73 \\
n & & Terlindung & 0,97 & 0,95 & 0,93 & 0,90 & 0,87 & 0,85 \\
$(\mathrm{RES})$ & \multirow{2}{*}{ kecil } & Terlawan & 0,98 & 0,93 & 0,88 & 0,83 & 0,80 & 0,74 \\
& & Terlindung & 0,98 & 0,96 & 0,94 & 0,91 & 0,88 & 0,86 \\
\hline
\end{tabular}

Sumber : Manual Kapasitas Jalan Indonesia (MKJI) 1997

c) Faktor penyesuaian untuk kelandaian sesuai Gambar 2.3

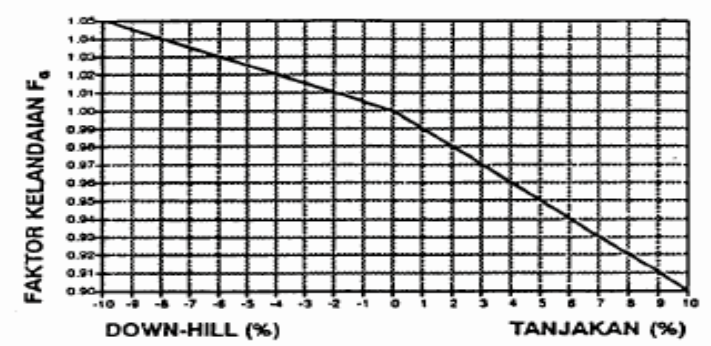

Gambar 3 Grafik faktor penyesuaian untuk kelandaian Sumber : Manual Kapasitas Jalan Indonesia (MKJI) 1997 
d) Faktor penyesuaian untuk pengaruh parkir dan lajur belok kiri yang pendek sesuai Gambar 4.

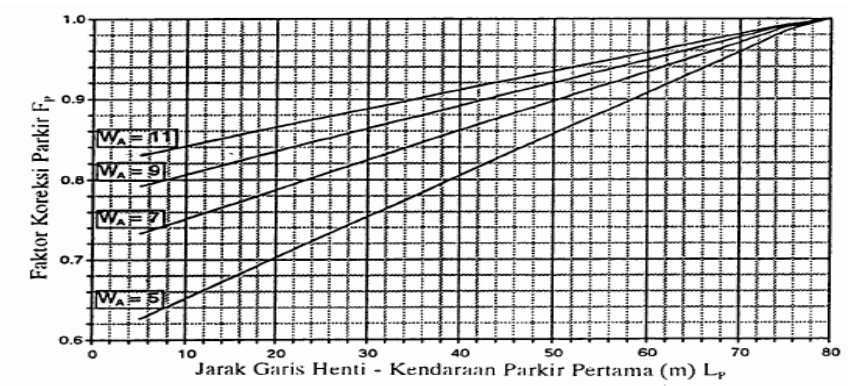

Gambar 4 Grafik faktor penyesuaian untuk pengaruh parkir dan lajur belok kiri yang pendek

Sumber: Manual Kapasitas Jalan Indonesia (MKJI) 1997

e) Factor penyesuaian belok kanan sesuai Gambar 5

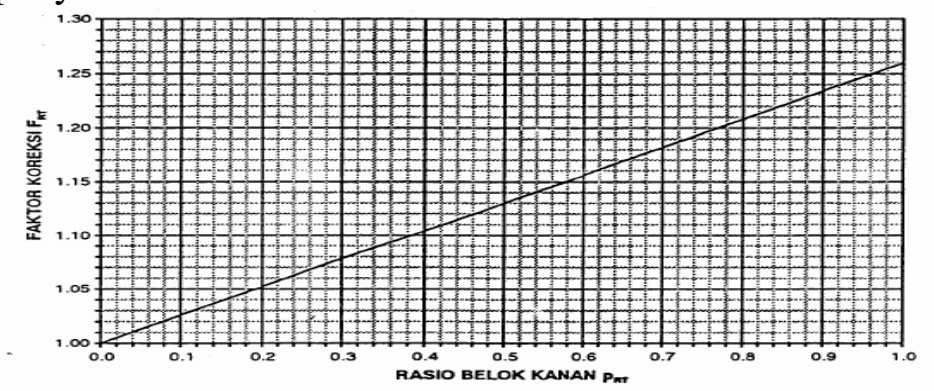

Gambar 5 Grafik faktor penyesuaian untuk belok kanan

Sumber : Manual Kapasitas Jalan Indonesia (MKJI) 1997

f) Faktor Penyesuaian untuk belok kiri sesuai Gambar 6

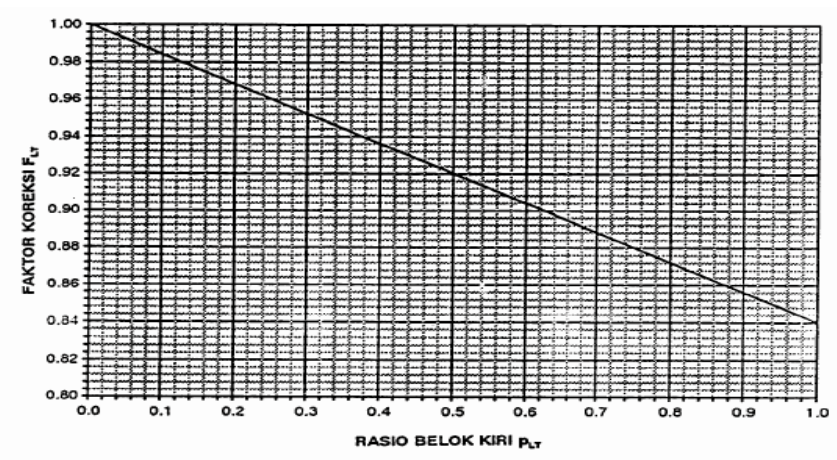

Gambar 6 Grafik faktor penyesuaian untuk belok kiri

Sumber: Manual Kapasitas Jalan Indonesia, 1997

2) Nilai arus jenuh

Jika suatu pendekat mempunyai sinyal hijau lebih dari satu fase, yang arus jenuhnya telah ditentukan secara terpisah maka nilai arus kombinasi harus dihitung secara proporsional terhadap waktu hijau masing-masing fase.

$$
S=S O x F C S \times F S F \times F G \times F P x F R T \times F L T
$$


Keterangan:

SO : Arus jenuh dasar Fp : Faktor koreksi parkir

FCS : Faktor koreksi ukuran kota FRT : Faktor Koreksi belok kanan

FSF : Faktor koreksi hambatan sampingFLT : Faktor Koreksi belok kiri

$\mathrm{FG}$ : Faktor koreksi kelandaian

\subsubsection{Perbandingan Arus Lalulintas Dengan Arus Jenuh (FR)}

Perbandingan arus lalulintas dengan arus jenuh keduanya menggunakan rumus berikut

$$
\mathrm{FR}=Q_{S}
$$

Keterangan: FR : Rasio Arus

Q : Arus Lalulintas (smp/jam)

$\mathrm{S}$ : Arus Jenuh (smp/jam)

Untuk arus kritis dihitung dengan rumus:

$$
\mathrm{PR}=\frac{(\text { FRcrit })}{\text { IFR }}
$$

Keterangan:

IFR : Perbandingan arus simpang $\Sigma$ (FRcrit)

PR : Rasio fase

FRerit : Nilai FR tertinggi dari semua pendekat yang berangkat pada suatu fase sinyal

\subsubsection{Waktu Siklus Waktu Hijau} Tabel 5

Adapun waktu siklus yang layak untuk simpang adalah seperti terlihat pada

Tabel 5 waktu siklus yang layak untuk simpang

\begin{tabular}{|c|c|}
\hline Tipe pengaturan & Waktu siklus (det) \\
\hline 2 fase & $40-80$ \\
3 fase & $50-100$ \\
4 fase & $60-130$ \\
\hline
\end{tabular}

Sumber: Manual Kapasitas Jalan Indonesia (MKJI) 1997

Waktu siklus yang tidak disesuaikan (c) berdasarkan waktu hijau yang diperoleh dan telah dibulatkan dan waktu hilang (LTI) dihitung dengan rumus :

$$
\mathrm{c}=\Sigma \mathrm{g}+\mathrm{LTI} \text {. }
$$

Keterangan:

$$
\begin{array}{ll}
\mathrm{c} & : \text { Waktu hijau (detik) } \\
\text { LTI } & : \text { Total waktu hilang per siklus (detik) } \\
\Sigma \mathrm{g} & : \text { Total waktu hijau }
\end{array}
$$

Waktu siklus dihitung dengan rumus :

$$
\text { Cua }=\frac{(0,5 x L T I+5)}{(1-I F R)}
$$

Keterangan:

Cua : Waktu siklus pra penyesuaian sinyal (detik)

LTI : Total waktu hilang per siklus (detik)

IFR : Rasio arus simpang

Waktu siklus pra penyesuaian juga dapat diperoleh dari Gambar 7 


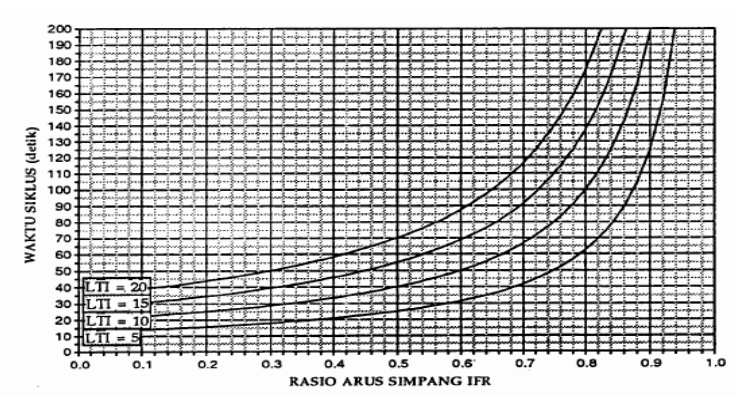

Gambar 7 grafik penetapan waktu siklus pra penyesuaian Sumber : Manual Kapasitas Jalan Indonbesia (MKJI) 1997

Waktu hijau (green time) untuk masing-masing fase menggunakan rumus : gi $=($ cua - LTI $) \times$ PRi $) \times$ PRi

keterangan:

$\begin{array}{ll}\text { gi } & \text { : Waktu hijau dalam fase-I (detik) } \\ \text { LTI } & \text { : Total waktu hilang per siklus (detik) } \\ \text { Cua } & \text { : Waktu siklus pra penyesuaian sinyal (detik) } \\ \text { PRi } & \text { : Perbandingan fase FRkritis/L(FRkritis) }\end{array}$

\subsection{Kapasitas}

Penentuan kapasitas masing-masing pendekat dan pembahasan mengenai perubahan-perubahan yang harus dilakukan jika kapasitas tidak mencukupi.

a. Kapasitas untuk tiap lengan dihitung dengan rumus :

$$
\mathrm{C}=\mathrm{S} \times \frac{g}{c}
$$

keterangan:

C : Kapasitas (smp/jam)

$\mathrm{S}:$ Arus jenuh (smp/jam)

$\mathrm{g}$ : Waktu hijau (detik)

c : Waktu siklus yang disesuaikan (detik)

b. Derajat kejenuhan (DS) dihitung dengan rumus :

$\mathrm{DS}=\mathrm{Q} / \mathrm{C}$

keterangan:

Q : Arus lalulintas (smp/jam)

C : Kapasitas (smp/jam)

\subsection{Keperluan Untuk Perubahan}

Menurut MKJI (1997), jika waktu siklus yang telah dihitung memperoleh hasil lebih besar dari batasan, biasanya derajat kejenuhan juga mempunyai nilai lebih tinggi dari 0,85. Ini berarti bahwa simpang tersebut mendekati lewat jenuh, yang akan menyebabkan antrian panjang pada kondisi lalulintas puncak. Alternative tindakan yang diambil untuk menambah kapasitas simpang antara lain dengan penambahan lebar pendekat, perubahan fase sinyaql dan pelanggaran gerakan-gerakan belok kanan.

\section{Hasil dan Pembahasan}

Ruas jalan Merdeka Barat (arah Merdeka Barat-Merdeka Timur) berupa jalan masuk utama dan pusat pelayanan lalulintas Kota Lhokseumawe untuk arah utara, pergerakan dari luar Kota Lhokseumawe. Ruas jalan Merdeka Timur (arah 
Merdeka Timur-Merdeka Barat) merupakan jalan keluar dari pusat pertokoan di kota Lhokseumawe, jalan Pang Lateh adalah jalan yang di dalamnya terdapat daerah permukiman sedangkan pergerakan dari jalan Darussalam (kawasan pertokoan dan pemukiman) adalah pergerakan yang paling dominan terjadi di jalan Merdeka Barat.

Hasil survei pada bulan September tahun 2012 menunjukkan jumlah arus lalulintas yang cukup stabil kecuali pada jam puncak (pada pagi dan sore hari) terutama pada lengan barat dan lengan utara. Jumlah arus (Q) yang keluar lengan cukup tinggi dan akan terjadi kenaikan kapasitas jalan pada saat jam puncak.
a. Keluar dari lengan Timur : $823 \mathrm{smp} / \mathrm{jam}$
b. Keluar dari lengan Barat $\quad: 843 \mathrm{smp} / \mathrm{jam}$
c. Keluar dari lengan Utara : $233 \mathrm{smp} / \mathrm{jam}$
d. Keluar dari lengan Selatan : $258 \mathrm{smp} / \mathrm{jam}$

\subsection{Arus Jenuh Dasar}

Arus jenuh dasar untuk simpang Empat dihitung menggunakan rumus 1 diperlihatkan pada Tabel 6. Lebar efektif (We) untuk masing-masing pendekat adalah sebagai berikut :

\section{Tabel 6 Perhitungan Arus Jenuh Dasar}

\begin{tabular}{|c|c|c|c|}
\hline Pendekat & Tipe Pendekat & Lebar Efektif & Arus Jenuh Dasar \\
\hline Timur & P (terlindung) & $8 \mathrm{~m}$ & $4800 \mathrm{smp} / \mathrm{jam}$ \\
\hline Barat & P (terlindung) & $12 \mathrm{~m}$ & $7200 \mathrm{smp} / \mathrm{jam}$ \\
\hline Utara & O (terlawan) & $4 \mathrm{~m}$ & $1960 \mathrm{smp} / \mathrm{jam}$ \\
\hline Selatan & O (terlawan) & $4,5 \mathrm{~m}$ & $2200 / \mathrm{jam}$ \\
\hline
\end{tabular}

\subsection{Nilai Arus Jenuh (S)}

Arus jenuh yang terdapat pada Tabel 6 didapat berdasarkan masing-masing tipe pendekat. Untuk pendekat timur dan pendekat barat tipe pendekatnya adalah terlindung (P) sehingga Pendekat Timur sebesar 4800 smp/jam dan Pendekat Barat sebesar 7200 smp/jam sedangkan untuk pendekat Utara dan Selatan tipe pendekatnya adalah terlawan $(\mathrm{O})$, menurut MKJI nilai arus jenuh dasar didapat dari tabel diperlihatkan pada gambar 2. Pendekat Utara $\mathrm{We}=4 \mathrm{~m}$ sehingga nilai $\mathrm{S}$ nebjadi $1960 \mathrm{smp} / \mathrm{jam}$, Pendekat Selatan We = 4,5 m. Untuk We $=4 \mathrm{~m} ; \mathrm{S}=1960$ smp/jam, untuk We $=5 \mathrm{~m}$ maka $S=2440 \mathrm{smp} /$ jam sehingga $\mathrm{S}_{4.5}$ sebesar 2200 smp/jam. Setelah didapat nilai arus jenuh dasar di atas, maka dengan menggunakan rumus (2) akan diperoleh nilai arus jenuh Simpang Empat diperlihatkan pada Tabel 7

Tabel 7 Perhitungan Nilai Arus Jenuh

\begin{tabular}{|c|c|c|c|c|}
\hline & Timur & Barat & Utara & Selatan \\
\hline So & $\begin{array}{c}4800 \text { smp/jam } \\
\text { hijau }\end{array}$ & $\begin{array}{c}7200 \mathrm{smp} / \mathrm{jam} \\
\text { hijau }\end{array}$ & $\begin{array}{c}1960 \text { smp/jam } \\
\text { hijau }\end{array}$ & $\begin{array}{c}2200 \mathrm{smp} / \mathrm{jam} \\
\text { hijau }\end{array}$ \\
\hline $\mathrm{F}_{\mathrm{CS}}$ & 0,83 & 0,83 & 0,83 & 0,83 \\
\hline $\mathrm{F}_{\mathrm{SF}}$ & 0,93 & 0,93 & 0,95 & 0,95 \\
\hline $\mathrm{F}_{\mathrm{G}}$ & 1,00 & 1,00 & 1,00 & 1,00 \\
\hline $\mathrm{F}_{\mathrm{P}}$ & 1,00 & 1,00 & 1,00 & 1,00 \\
\hline$F_{R T}$ & 1,00 & 1,00 & 1,00 & 1,00 \\
\hline $\mathrm{F}_{\mathrm{LT}}$ & 1,00 & 1,00 & 1,00 & 1,00 \\
\hline $\mathrm{S}$ & $\begin{array}{c}3705 \mathrm{smp} / \mathrm{jam} \\
\text { hijau }\end{array}$ & $\begin{array}{c}5558 \mathrm{smp} / \mathrm{jam} \\
\text { hijau }\end{array}$ & $\begin{array}{c}1545 \mathrm{smp} / \mathrm{jam} \\
\text { hijau }\end{array}$ & $\begin{array}{c}1735 \mathrm{smp} / \mathrm{jam} \\
\text { hijau }\end{array}$ \\
\hline
\end{tabular}




\subsection{Perbandingan Arus Lalulintas Dengan Arus Jenuh (FR)}

Hasil perhitungan nilai arus jenuh pada tabel 7 dan nilai Q untuk masingmasing pendekat dapat diperoleh nilai rasio arus (FR) menggunakan rumus 3 dan nilai rasio fase menggunakan rumus 4 maka dapat diperoleh Rasio Arus Simpang (IFR) yang diperlihatkan pada tabel 8 .

Tabel 8 Perhitungan Rasio Arus dan Rasio Fase

\begin{tabular}{|c|c|c|c|c|}
\hline Pendekat & Q & $S$ & FR & PR \\
\hline Timur & $823 \mathrm{smp} / \mathrm{jam}$ & $3705 \mathrm{smp} / \mathrm{jam}$ hijau & 0,222 & 0,425 \\
\hline Barat & $843 \mathrm{smp} / / \mathrm{jam}$ & $5558 \mathrm{smp} /$ jam hijau & 0,152 & 0,29 \\
\hline Utara & $233 \mathrm{smp} / \mathrm{jam}$ & 1545 smp/jam hijau & & \\
\hline Selatan & $258 \mathrm{smp} / \mathrm{jam}$ & $1735 \mathrm{smp} / \mathrm{jam}$ hijau & 0,149 & 0,285 \\
\hline & & IFR $=\Sigma$ FRcrit & 0,523 & \\
\hline
\end{tabular}

\subsection{Waktu siklus $\left(c_{\text {ua }}\right)$ dan waktu hijau $(\mathrm{g})$}

Waktu siklus $\left(\mathrm{c}_{\mathrm{ua}}\right)$ merupakan waktu untuk pengendalian waktu tetap yang dihitung menggunakan persamaan 2.6 seperti diperlihatkan Tabel 9.

Tabel 9 Perhitungan Waktu Hijau

\begin{tabular}{|c|c|c|c|}
\hline Pendekat & LTI & $\mathrm{c}$ & $\mathrm{Gi}$ \\
\hline Timur & \multirow{4}{*}{14 detik } & \multirow{4}{*}{54,486 detik } & 30 \\
\hline Barat & & & 32 \\
\hline Utara & & & 27 \\
\hline Selatan & & & 27 \\
\hline & & $\Sigma \mathrm{g}$ & 116 \\
\hline
\end{tabular}

Simpang Empat merupakan simpang yang memiliki 3 fase, untuk tipe pengaturan tiga fase waktu siklus $\left(\mathrm{c}_{\mathrm{ua}}\right)$ yang di sarankan MKJI adalah $50-100$ detik. Nilai-nilai yang lebih rendah dipakai untuk simpang dengan lebar jalan $<10$ $\mathrm{m}$, nilai yang lebih tinggi untuk jalan yang lehih lebar.

\subsection{Kapasitas (c) dan derajat kejenuhan (ds)}

Kapasitas dan Derajat Kejenuhan Simpang Empat dihitung menggunakan persamaan 8 dan 9, hasil perhitungan diperlihatkan pada Tabel 10.

\section{Tabel 10 Perhitungan Kapasitas dan Derajat Kejenuhan}

\begin{tabular}{|c|c|c|c|}
\hline Pendekat & Arus Lalulintas & Kapasitas & Derajat Kejenuhan \\
\hline Timur & $823 \mathrm{smp} /$ jam & $2040 \mathrm{smp} / \mathrm{jam}$ & 0,40 \\
\hline Barat & $843 \mathrm{smp} /$ jam & $3264 \mathrm{smp} / \mathrm{jam}$ & 0,26 \\
\hline Utara & $233 \mathrm{smp} / \mathrm{jam}$ & $766 \mathrm{smp} / \mathrm{jam}$ & 0,30 \\
\hline Selatan & $258 \mathrm{smp} / \mathrm{jam}$ & $860 \mathrm{smp} / \mathrm{jam}$ & 0,30 \\
\hline
\end{tabular}

\subsection{Arus Lalulintas}

Arus lalulintas puncak pada simpang ini terjadi pada pagi dan sore hari. Untuk perhitungan, arus lalulintas yang diambil adalah pada saat jam puncak pagi hari senin-jum'at dan jam puncak sore untuk hari sabtu dan minggu (mengingat arus lalulintas paling tinggi pada simpang ini terjadi di pagi hari dan untuk hari sabtu dan minggu arus lalulintas meningkat pada sore hari). Arus lalulintas yang terjadi pada hari senin-jum'at, diperlihatkan pada Gambar 8. 


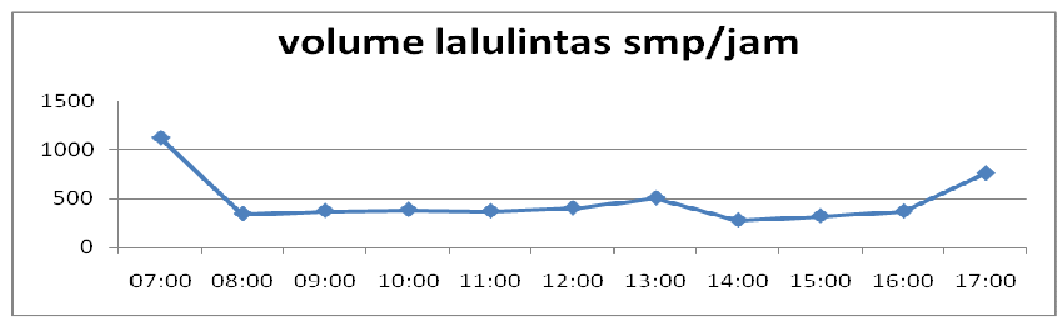

Gambar 8 volume lalulintas

Gambar 8 menunjukkan bahwa jam puncak terjadi pada pagi hari antara pukul 07.00-08.00 karena pada jam tersebut waktu keberangkatan untuk pengguna jalan yang umumnya pegawai pemerintahan dan jam pergi sekolah untuk anak-anak sekolah. Sehingga arus masuk dan keluar pada simpang tersebut meningkat.

\subsection{Kapasitas dan Derajat Kejenuhan}

Kapasitas merupakan arus lalulintas maksimum yang dapat melewati suatu pendekat. Arus lalulintas pada Simpang Empat belum mencapai angka maksimum karena arus yang melintasi masing-masing pendekat merupakan arus stabil. Derajat kejenuhan merupakan alat ukur untuk mengetahui tingkat pelayanan jalan. Semakin besar nilai DS berarti tingkat pelayanan jalan tersebut semakin buruk. Pada Simpang Empat, pendekat yang memiliki nilai DS paling tinggi adalah pendekat timur yaitu sebesar 0,40 (terlihat pada lampiran A.44). Ini disebabkan karena arus lalulintas pada pendekat ini merupakan arus keluar kota Lhokseumawe dengan lebar efektif 8 dan pada pendekat tersebut sering sekali terdapat kendaraan yang parkir di badan jalan. Hal ini disebabkan karena terdapat pertokoan pada lengan simpang tersebut sehingga lebar efektif jalan berkurang.

\section{Kesimpulan dan Saran}

\subsection{Kesimpulan}

Berdasarkan hasil dari analisis terhadap Simpang Empat Kota Lhokseumawe, dapat disimpulkan bahwa:

1. Kapasitas untuk pendekat timur $2040 \mathrm{smp} / \mathrm{jam}$, pendekat barat $3264 \mathrm{smp} / \mathrm{jam}$, pendekat utara $766 \mathrm{smp} / \mathrm{jam}$ dan pendekat selatan $860 \mathrm{smp} / \mathrm{jam}$.

2. Ruas jalan Merdeka Barat memiliki nilai ds 0,26 ruas jalan Merdeka Timur 0,40 ruas jalan Darussalam 0,30 dan ruas jalan Panglateh 0,30. Dari keempat ruas jalan tersebut yang memiliki nilai ds paling tinggi adalah ruas jalan merdeka timur.

3. Nilai DS yang tinggi pada pendekat timur (jalan Merdeka Timur) disebabkan karena adanya pertokoan di lengan jalan tersebut sehingga kendaraan melakukan parkir sembarangan yang mengakibatkan lebar efektif jalan tersebut terganggu

\subsection{Saran} berikut:

Dari hasil penelitian ini maka saran yang dapat diberikan saran sebagai

1. Waktu survei untuk pendataan volume lalulintas sebaiknya dilakukan selama 24 jam sehari selama 1 (satu) minggu untuk mendapatkan lalulintas Harian Rata-Rata (LHR) yang lebih akurat 
2. Perlu diadakan koordinasi dengan aparat keamanan setempat untuk menjaga ketertiban para pengguna jalan dan pedagang kaki lima supaya tidak memanfaatkan ruang jalan dan trotoar sebagai tempat berjualan.

3. Seharusnya pada simpang IV Kota Lhokseumawe sudah memiliki 4 fase pengaturan lalulintas, alasannya disebabkan telah meningkatnya volume arus lalulintas harian dari pengaturan fase awal dan untuk mengurangi terjadinya titik konflik pada persimpangan tersebut.

\section{Daftar Kepustakaan}

1. Anonim, 1997, Manual Kapasitas Jalan Indonesia, Departemen Pekerjaan Umum, Dirjen Bina Marga, Jakarta.

2. Anonim, 2010. Evaluasi kinerja simpang tak bersinyal type $T$, Volume.6 No.1, http// www.jurnal_kinerja simpang.com. diunduh tanggal 26 april 2012

3. Jotin khisty, B. kent Lall. Dasar-Dasar Rekayasa Transportasi, ed. Ke-2/jilit 1, Erlangga, Jakarta

4. Linasih, muji, 2007, Analisis kapasitas dan kinerja pada simpang bersinyal, httt// www.jurnal.com. Diunduh tanggal 5 juni 2011

5. Morlok, Edward K, 1995, Pengantar Teknik dan Perencanaan Transportasi, Erlangga, Jakarta

6. Suwardjoko P. Warpani, 2002, Pengelola Lalu Lintas Dan Angkutan Jalan. Penerbit ITB, Bandung

7. Tamin, ofyar Z, 2000, Perancangan Dan Permodelan Transportasi ed. Ke-2/ ofyar Z Tamin.- Bandung: - Penerbit ITB

8. Tamin, O Z, 2003, Perencanaan Dan Pemodelan Transportasi, Contoh Soal dan Aplikasi, Penerbit ITB, Bandung 